\title{
A Strategy of Preparing Character Social Science Teachers
}

\author{
Wahyu \\ Civics Education Study Program, Faculty of Teacher Training and Education \\ Lambung Mangkurat University \\ Banjarmasin, Indonesia \\ wahyu@gmail.com
}

\begin{abstract}
Lately, school teachers graduated intelligent students who lack awareness of the importance of moral values and manners in school life and society. This is due to what students are showing is also learning outcomes, both directly and indirectly. Therefore, in short, a school tends to be a place knowledge transfer rather than character building; merely a place of teaching rather than educating. Considering the various facts above, the preparation of character teachers is an important and strategic step in rebuilding the character of students in schools who believe, devoted to God Almighty, have a noble character, are healthy, knowledgeable, capable, creative, independent, democratic, and responsible. This article reviewed some literature and theories to propose a strategy of preparing character social science teachers. Based on the study, the strategies are (1) Teachers must show their principles in teaching with how to treat their students with compassion, (2) Teachers should establish themselves as a teacher who not only transfers his/her knowledge, (3) Teachers should internalize rules that come from outside and becomes the norm and value in their life, (4) Teachers loyalty to their choice further encouraged them to continue working hard in educating his/her students with patience and diligence.
\end{abstract}

Keywords-strategy; preparing; characters; social science teachers

\section{INTRODUCTION}

When various cities scattered in Japan, including Tokyo bombed by US aircraft during the Pacific War, the Emperor of Japan laid down on the floor for a long time, he stood up straight and said with emotion, "How many teachers are still alive? We will immediately rise again and become an honorable nation on earth". There is another story in 1942 about the invasion of the Nazi army Germany over Hitler's attacks that devastated a number of European countries, including Britain. In a state of emergency, the parliament took an initiative to call the Prime Minister (PM) England, Winston Churchill. PM Churchill was invited to discuss the addition of the military budget for war. Parliamentarians urged the government to reduce the education budget and divert it into the military budget to strengthen weapons. Hearing the pressure of the parliament, Churchill stood in the pulpit and raised his index finger, "Dear gentlemen, don't you forget? you are sitting in this room because of education" [1].
The two great leaders had shown a high commitment to education, especially teachers. They did not falter with pressure and maintain their views that are concerned with education even in the midst of war and conflict in their country. Their statements and attitudes further inspire us. If a nation wants to leave a gray past and save the future, the nation can only do so through education. Apart from that, there is still another story about Bill Clinton. On his way to be the number one in the US, Clinton made the issue of education as the central theme of his campaign towards the President's position. The issue turned out to attract the sympathy of the voters so that it led him to become the US President, even for two periods (1992-2000)

Therefore, education is the biggest investment we have to do. The facts show that natural resource-poor countries, such as Japan, Singapore, and European society, are respectable nations not because of their natural resources, but it is because of the education. We must educate and graduate intelligent students to continue to be a respectable nation stated Clinton in his campaign [1]

To prepare excellent human beings, such as thinking critically, creatively, innovatively, and productively, as well as believing and fearing God in the learning process, a series of supporting factors is needed. They are such as curriculum, teaching materials, and teachers who are expected to improve the quality of students. Further, a question arises. Which one is more important, curriculum or teachers? It is probably found that most of us agree that the answer is teachers. Indeed, it cannot be denied anymore that teacher is the most responsible people in transferring knowledge to students. Teachers also develop abilities while forming a dignified national character and civilization. Without intending to dramatize, the teacher also plays a major role in making citizens who believe, fear God, morality, health, knowledge, skillful, creative, independent, democratic, and responsible.

One interesting point from a Poetry part conveyed by Winarno Surakhmad on the 60th Teacher's Day, Sunday, November 27, 2005, at the Manahan Surakarta Stadium, is as follows:

Arise, arise my teacher,

Your presence is irreplaceable,

Let this world be a witness.

You're not a state teacher,

You're not a private teacher, 


\section{You Are The Nation Teacher!}

In a mindset that is more or less the same as Winarno Surakhmad, the former Minister of Education and Culture, Fuad Hasan once argued: "No matter how good the curriculum is if it is not accompanied by qualified teachers, everything is in vain. In contrast, the curriculum is lacking good will be supported by qualified teachers" [2]. The statement of the two leaders of education provides inspiration. It is very important for all of us that teachers have a major role in improving the quality of the learning process in the classroom.

Understanding the description above, we can see how great the services of teachers are in helping the growth and development of students. In other words, the interests, talents, abilities, and potentials of the students will not be developed optimally without the help of the teacher. The teacher has a very large role and function in shaping the personality of the child, preparing human resources (HR), as well as the welfare of society, the progress of the country and nation.

\section{WHO IS A TEACHER?}

Everyone believes that a teacher has a huge contribution to the success of learning in school. The teacher has a very instrumental role in helping the development of students to reach their life goals optimally. This belief arises because humans are weak creatures and their development always requires other people since they were born and even when they die. All of that shows that everyone needs other people in their development, as well as students. When parents register their children to school, at that time they also hope teacher to facilitate their children develop optimally.

Understanding the description above, the services of the teacher in helping the growth and development of students are great. Thus, a teacher must be a true pluralist and place himself/herself as a model for students. For example, honest behavior from a teacher in the eyes of students is the capital towards education in a better direction. Children need examples, role models, or good role models from the teacher.

Therefore, "Who is a teacher?" Many definitions arise about who the teacher is. Linguistically, the term teacher is found in all world languages. In English, for example, the term teacher and the Indonesian language is guru. The teacher has a meaning: A person whose occupation is teaching others, namely someone whose job is teaching others [3]. In Arabic, the teacher is known to be other terms and one of them is mu'alim, which is someone who makes others knowledgeable or people who convey information to others.

According to the [4], a teacher is a human with the main task (profession) of teaching, whereas according to Vembrianto a teacher is a professional educator in the school with the task of teaching.

On the Law of Republic Indonesia No. 14 of 2005 concerning Teachers and Lecturers, Article 1, it is stated that teachers are professional educators with the task of educating, teaching, guiding, directing, training, and evaluating students in early childhood education in formal education, basic education, and secondary education. Another term that still concerns the teacher and develops in the community is the educator.

Constitutionally, on the Article 1 of Law Number 20 of 2003 concerning the National Education System, it is explained that educators are qualified educational staff as teachers, lecturers, counselors, tutors, widyaiswara, tutors, instructors, facilitators, and other designations that are in accordance with their specificities, and participate in organizing education. In Article 39 paragraph 2 of the same law, it is also explained that teachers are also referred to as educators, with the meaning that educators are professionals who are tasked with planning and carrying out the learning process, assessing learning outcomes, guiding and training, and conducting research and community service especially for educators in universities.

Apart from the above concerns, there are several expert opinions about the characteristics that must be possessed by the teachers, including the following:

- Teacher's requirements are has a diploma, physically and mentally health, piety to God Almighty, wellbehaved, responsible, national spirit, fair, trusting and like to his students, patient and willing to sacrifice, have authority over children, cheerfull, kind to other teachers, kind to the community, truly master their subjects, like the subjects they are given, and knowledgeable.

- According to An-Nahlawi in [5], the characteristics of a teacher are having goals, and behavior. In addition, the mindsets of a teacher are sincere, patient, honest, equips themselves with the knowledge of being able to use teaching methods, able to manage students, study psychic life students, responsive to various problems, and be fair.

- In Al-Abrasyi's view [5], the characteristics of an Islamic teacher include body, clean soul, not vindictive, dislike hostility, not ashamed to admit ignorance, firm in words and deeds, wise, sincere, humble, gentle, forgiving, patient, personable, not feeling inferior, fatherly, and know the character of the students.

- According to Yunus in [6], the characteristics of a teacher, among others, are compassion for students, wise in choosing learning materials, happy to prohibit students from doing things that are not good, happy to give warnings, happy to give advice, respect other lessons that are not his/her grip, wise in choosing learning materials that are in accordance with the level of intelligence of students, prioritize thinking, honest in science, and fair.

Meanwhile, the research results of [7] show that teachers according to the Banjarese community have two categories, namely formal teachers and non-formal teachers. Formal teachers are teachers who have several criteria, namely educated teacher, work in accordance with the field of their study, teach in a class, and devote their lives to teaching and learning. The other one, non-formal teachers are another name for people who dedicate themselves to the benefit of the people. They are usually in the midst of the community to teach in the form of recitation and other religious knowledge. 
This teacher does not have a special class even though there is a place where he is in a mosque, prayer room, or another Islamic council. Non-formal teachers are certainly seen from exemplary behavior and daily actions. The names of nonformal teachers such as Tuan Guru or Urang Alim, Guru ngaji or the teacher of the Al-Qur'an reading in the village, Guru Yasinan, Guru Maulid Habsi are other familiar names named according to the conditions of each area in every place that has a different culture.

Both formal and non-formal teachers, in addition to providing their knowledge to their students, also provide advice and educate their minds. Therefore, according to the Banjarese community, a teacher must have authority in the community. The authority will arise when guarding the mouth against harsh words, namely words and temperaments that are gentle, suave, polite or manly. Authority is also indicated by the existence of social attitudes in the community, for example like to help or contribute, and like to provide solutions (discordant suggestions) in solving community problems.

In the view of the Banjarese community, non-formal teachers usually get more respect and trust than formal teachers. This happens because non-formal teachers have a study area of multidimensional and multi-association workspace so that every word, deed, and behavior is always followed by the Banjar community. In other words, non-formal teachers lie in simplicity both in attitude and speech in daily life.

There are other interesting things namely teachers in the view of [8], teachers at SMAN 2 Kabupaten Demak. According to [8], we all really miss the emergence of slick, smart and bright teachers. First, a slick teacher is a courageous and steadfast teacher to the principles, is not to be easily swayed in any situation, is not be afraid to take risks, has the firmness of idealism, durability, a loyalty to the profession, to set an example as a human being cultured or civilized, well-mannered noble, expert, disciplined, honest, trustworthy in their duties, and has a positive self-image.

Second, a smart teacher is a teacher who can motivate students, be inspired by empathy, sympathy, and enthusiasm for achievement, has fighting spirit, master the knowledge they have to teach, be able to teach them in ways that are creative, fun, interesting, easy and clear to captured by children and pervasive in children, follow the progress of the times, innovative, like new things related to the learning model, use a variety of teaching aids, and build the conditions of the learning process based on the excitement of students and teachers.

Third, a teacher has good moral, and moral concerns kindness. Teachers who are not good are also referred to as immoral people. Therefore, simply moral is a standard of values about which actions are good and which are bad. Moral violations are always condemned as a thing because they cannot be morally justified. An example is a teacher or a success team that provides answers to students at the time of the State Examination (UN) with the aim of their National Exams to graduate. The action of the teacher or team of success is not good and can be called a teacher or a team of unscrupulous success.

Based on the description above, perhaps none of us disagrees that the teacher has a big and noble role. $\mathrm{He} / \mathrm{she}$ is like the spearhead and the front guard for the nation's education. If you want to see the quality of education of a nation, first look at the quality of the teacher. Because, whatever the system, software and hardware of education of a nation without being supported by the quality and professionalism of the teacher, is small the possibility of the nation's education concerned achieving success.

\section{WHAT IS A CHARACTER?}

The word "character" comes from Latin word namely "kharakter", "kharassein" and "kharax" which means tools for marking, to engrave, and pointed stake. This word began to be widely used in French as "caractere" in the 14th century. When it entered into English, the word "caractere" changed to "character." Then, in Indonesian, the word "character" becomes "karakter" [9].

According to the American Dictionary of the English Language, the character is a term that shows the application of good values in the form of actions or behavior. Meanwhile, according to Poerwodarminta, the character is defined as character, character, psychological traits, and character or character that distinguishes a person from others.

According to [10], a character is a person's nature in responding to situations morally. Nature is manifested in real action through good, honest behavior, responsible for respecting and respecting others, and other noble characters. Meanwhile, according to Winnie [11], the term character has two meanings. First, it shows how someone behaves. If someone behaves dishonestly, cruelly, or greedily the person manifests bad behavior. Conversely, if someone behaves honestly, is helpful, surely that person manifests noble character. Second, the term character is closely related to personality. A person can be called a person of character if his behavior is in accordance with moral rules.

Meanwhile, according to the Ministry of Education, the character is the personality of a person formed from the results of the internalization of virtues, which are believed and used as a basis for perspective, thinking, acting and acting. Therefore, based on several definitions of character that have been described, the character is actually a person's nature in responding to situations morally. If someone behaves dishonestly, cruelly, or greedily, he/she is hereinafter referred to as a bad character. Conversely, if someone behaves well, honestly, responsibly, respectfully to others, and other noble character values, he/she has a good character.

Good moral character as mentioned above cannot be owned by every individual because it requires an effort to character education effectively. In the opinion of some experts namely [10], [11] there are at least six noble characters that can be applied to character education, namely as follows:

- Trustworthiness

- Respect (treat others with respect), 
- Responsibility

- Fairness

- Caring (attention, affection, and caring),

- Citizenship (acting as a good citizen).

Completing the description above, Ref. [12] one of the originators of character education in Indonesia has compiled nine pillars of noble character which should be used as a reference in character education, both at school and outside of school as follows:

- God's love and truth,

- Responsibility, discipline, and independence,

- Trust,

- Respect and courtesy

- Affection, care, and cooperation,

- Confident, creative, and never give up,

- Fair and spirit of leadership,

- Good and low self-esteem,

- Tolerance and love peace.

Therefore, to make character education more effective, further collaboration between schools, parents, communities and the government is needed, both in planning, implementation, evaluation, and supervision.

\section{TEACHER MUST HAVE CHARACTERS}

As a teacher, does the teacher feel that he/she has characters all this time? What kind of characters should a teacher have? According to the author, the teacher becomes the main spirit of education, so he/she must have all the good and noble characters. It is true that a teacher is an ordinary human who can be wrong, forget, and cannot be separated from other bad characters. However, apart from that, the noble character is important and must be more dominantly owned and stand out from the person of a teacher.

According to the Ministry of National Education, there are some noble values that must be possessed and practiced by the teacher before being taught to students in real life. The noble values are as follows:

TABLE 1. VALUE AND DESCRIPTION OF TEACHER CHARACTER VALUES

\begin{tabular}{|c|l|}
\hline Value & \multicolumn{1}{|c|}{ Description } \\
\hline \multirow{3}{*}{ Religious } & $\begin{array}{l}\text { Obedient attitudes and behavior in carrying out } \\
\text { the teachings of the religion they embrace, are } \\
\text { tolerant of the implementation of other } \\
\text { religious practices and live in harmony with } \\
\text { other religious adherents. }\end{array}$ \\
\hline Honest & $\begin{array}{l}\text { Behavior is based on efforts to make } \\
\text { himself/herself a person who can always be } \\
\text { trusted in words, actions, and work. }\end{array}$ \\
\hline Tolerance & $\begin{array}{l}\text { Attitudes and actions that respect differences in } \\
\text { religion, ethnicity, opinions, attitudes, and }\end{array}$ \\
\hline
\end{tabular}

\begin{tabular}{|c|c|}
\hline Value & Description \\
\hline & actions of others are different from his/hers. \\
\hline Discipline & $\begin{array}{l}\text { Actions that show orderly behavior and adhere } \\
\text { to various rules and regulations. }\end{array}$ \\
\hline Hard work & $\begin{array}{l}\text { Behavior that shows genuine effort in } \\
\text { overcoming various learning and task } \\
\text { problems, after completing the task as well as } \\
\text { possible. }\end{array}$ \\
\hline Creative & $\begin{array}{l}\text { Think and do something to produce new ways } \\
\text { or results from something that has been owned. }\end{array}$ \\
\hline Mandiri & $\begin{array}{l}\text { Attitudes and behaviors that are not easily } \\
\text { dependent on others in completing tasks. }\end{array}$ \\
\hline Democratic & $\begin{array}{l}\text { The way to think, behave and act that assesses } \\
\text { the rights and obligations of himself/herself } \\
\text { and others. }\end{array}$ \\
\hline Desire & $\begin{array}{l}\text { Attitudes and actions that always strive to } \\
\text { know more deeply and extensively from } \\
\text { something they learn, see and hear. }\end{array}$ \\
\hline Nationality Spirit & $\begin{array}{l}\text { The way of thinking, acting and having insight } \\
\text { that places the interests of the nation and the } \\
\text { state above the interests of themselves and } \\
\text { their groups. }\end{array}$ \\
\hline Love the country & $\begin{array}{l}\text { The way to think, behave and act that shows } \\
\text { loyalty, caring, and high appreciation for the } \\
\text { language, physical environment, social, } \\
\text { economic culture, and national politics. }\end{array}$ \\
\hline $\begin{array}{c}\text { Appreciate } \\
\text { Achievement }\end{array}$ & $\begin{array}{l}\text { Attitudes and actions that encourage } \\
\text { themselves to produce something that is useful } \\
\text { for the community, and recognizes as well as } \\
\text { respect the success of others. }\end{array}$ \\
\hline $\begin{array}{c}\text { Friendly/ } \\
\text { Communicative }\end{array}$ & $\begin{array}{l}\text { Actions that show pleasure in talking, } \\
\text { associating, and collaborating with others. }\end{array}$ \\
\hline Love peace & $\begin{array}{l}\text { Attitudes, words, and actions that cause other } \\
\text { people to feel safe and secure in their presence. }\end{array}$ \\
\hline $\begin{array}{l}\text { Fond of } \\
\text { Reading }\end{array}$ & $\begin{array}{l}\text { The habit of providing time to read various } \\
\text { passages that give virtue to him/her. }\end{array}$ \\
\hline $\begin{array}{l}\text { Environmentally } \\
\text { friendly }\end{array}$ & $\begin{array}{l}\text { Attitudes and actions that always strive to } \\
\text { prevent damage to the surrounding natural } \\
\text { environment, and develop efforts to repair the } \\
\text { natural damage that has occurred. }\end{array}$ \\
\hline Care for Social & $\begin{array}{l}\text { Attitudes and actions that always want to give } \\
\text { help to other people and people in need. }\end{array}$ \\
\hline Responsible & $\begin{array}{l}\text { The attitude and behavior of a person to carry } \\
\text { out his/her duties and authority, which he/she } \\
\text { should do towards oneself, society, } \\
\text { environment (social and culture), state and God } \\
\text { Almighty. }\end{array}$ \\
\hline
\end{tabular}

Based on the abovementioned points, a teacher is the main actor of learning. Teachers who have characters become the key to an organizing learning and constructive education for the lives of students. Thus, a teacher determines the success or failure of the learning process. If it is associated with character education which is currently becoming a government mainstay, the role of a teacher is very important. In short, the role of a teacher in the success of internalizing character education to students is the key. Other factors such as curriculum, culture, and spontaneous activities support the teacher.

In addition to having to have understanding, skills, and competencies regarding character, a teacher is also required to have those noble characters in himself/herself. He/she practices these characters in daily life both at school and in society and makes it a part of life. A teacher before teaching or internalizing the characters to the students must first emit the noble characters in the teacher concerned. 
Again, character teachers are fixed point. a similar statement is also conveyed by [13]. An interesting point conveyed by Hidayatullah is that character teachers become very important so that the concerned could organize education, learning, and develop the character of their students.

Therefore, according to [9], the main characters that must be possessed by a teacher are as follows:

\section{1) Commitment}

Commitment as a teacher is the determination to carry out their duties and responsibilities as an educator. If a teacher has a high commitment, he/she will have the sharpness of vision, sense of belonging, and responsibility for the mandate carried out.

\section{2) Competent}

Competent means the ability of the teacher to carry out learning and solve various problems in order to achieve educational goals. A competent teacher is characterized by expertise in his field, animating the profession he/she has, having pedagogical, personal, social, and professional competencies.

\section{3) Hard work}

Teachers must always work hard in carrying out their duties, especially in internalizing character education for their students. Among the indicators of a hard-working teacher are: (a) working sincerely and truly; (b) working beyond the target, and (c) being productive.

\section{4) Consistent}

Consistent is the ability to do something keenly, steady, focused, patient, and resilient, and make continuous improvements. This consistent character becomes a marker if the teacher has inspired and lived his/her profession. The consistency of the teacher is not only in words but also between words and deeds. Among the consistent teacher indicators are: (a) having principles; (b) keen and diligent; (c) patient and resilient; and (d) focus.

\section{5) Simple}

Simplicity should always be shown by the teachers. Simplicity is not identical to poverty. Someone who has a simple gift does not mean that the person does not own property. When the teacher looks simple, that does not mean the teacher is poor. The simplicity of a teacher radiates in behavior and among these indicators is (a) modest; (b) not luxurious, both appearance and model life; (c) is not excessive in using anything, and (d) is appropriate, meaning that he/she uses everything appropriately and has a positive use or contribution.

\section{6) Ability to interact}

The ability to interact is the ability to interact dynamically in the emotional connection between the teacher and students in order to achieve learning goals. A teacher should be able to interact well and effectively.

\section{7) Serve optimally}

Maximum service in education for students is a necessity so that the teacher must help serve and meet the needs of students in order to make their potential can be optimally empowered.

\section{8) Intelligent}

Teachers who are smart in reading the lives of their students' education are keywords so that students are then able to become smart learners. Therefore, smart teacher indicators are: (a) understand quickly, be responsive, analyze things deeply, and able to find alternative solutions; and (b) able to give meaning/value to various activities carried out so that the results are optimal.

Then, the question is how to yield teachers of character. Admittedly or not, character education and how to subsequently yield teachers of character are at least reminding us of one of the originators of character education that emphasizes the ethical-spiritual dimension in the process of personal formation. This person was a German FIN Foerster pedagogue (1869-1966). According to his opinion, the purpose of education is to form the character manifested in the essential unity of the subject with the behavior and attitude of life it has. There are four basic characteristics in character education as they are conveyed:

- Interior order with each action is measured based on the value hierarchy. The value of being normative guidance of every action. In other words, the principle in life is then translated into actions. The actions produced also provide good value for all. This level of kindness certainly brings satisfaction to all. Teachers in this context must be able to do that by showing their principles in teaching with how to treat their students with compassion. The affection that is given also brings good educational value to all;

- Coherence gives the courage to make a person firm on principle and not easily swayed to new situations or fear of risk. It is the basis for building trust with one another. A teacher in this context has established himself/herself as a teacher who not only transfers his/her knowledge. However, more than that is forming good individuals who are strict in guiding students. Every word and action was taken for their students has been thought through carefully. The teacher acts with a thought first, whether it is good or not for the formation of the mentality of their students.

- The third is autonomy. A teacher has internalized rules that come from outside and becomes the norm and value in his/her life. When the teacher conveys something to students, it is indeed seen as right and good. Anyone cannot and does not have the right to intervene. The teacher already knows what to do and do not. The teacher already understands what is best for the education of his/her students;

- Firmness is the endurance of a person in achieving something that is considered the best in his/her life in the future while loyalty is the foundation for respect for the commitment that has been chosen. When someone has decided to be a teacher, he/she is then truly determined to graduate good students. A teacher's loyalty to his/her choice further encouraged the teacher to continue working hard in educating his/her students with patience and diligence. 


\section{CONCLUSION}

A teacher is the main actor of learning. Therefore, the teacher is very critical of the success or failure of the learning process. If it is associated with character education which is currently the mainstay of the government, the role of the teacher is very important. A teacher, besides having to have understanding, skills, and competence regarding character, he/she is also required to have those noble characters in himself/herself, implement them and make them as part of his/her life. These noble characters include behaving well, being honest and helpful. In addition, the main character that must be possessed by the teacher is a commitment to competency, hard work, consistency, simplicity, ability to interact, serve optimally, and smart.

Thus, being a teacher who is able to merge with the lives of his/her students is a necessary thing for the real teacher when he/she is able to provide the best service for the lives of students. The teacher is like a torch in the middle of a pitchblack night that illuminates the journey of every student's life. Every step was taken by students where the direction is part of the teacher's upbringing. Everything that the students think and do is a duplication of the teacher's life. Teachers in this context not only transfer knowledge but also life values in science. The teacher introduces students to a wider world so that he/she is at least like a guide who will bring his/her students to know many things. Character teachers must then be able to answer the interests of future education.

\section{REFERENCES}

[1] R. H. Cahyono, "Sang Guru," Kompas, p. page 5.

[2] P. P. Astuti, "Tanpa Guru, Murid Tak Bermutu," Kompas, p. page 4.

[3] M. Syah, Psikologi Pendidikan: Sebuah Pendekatan Baru. Bandung: Rosda Karya, 1995.

[4] D. P. Nasional, Kamus Besar Bahasa Indonesia. Jakarta: Balai Pustaka, 2001.

[5] Mahmud, Sosiologi Pendidikan. Bandung: CV. Pustaka Setia, 2012.

[6] A. Tafsir, llmu Pendidikan dalam Perspektif Islam. Bandung: Remaja Rosda Karya, 1994.

[7] Wahyu, "Guru dalam Pandangan Orang Banjar," Banjarmasin, 2012.

[8] Susilo, "Rindu Guru yang Apik, Pinter dan Pener," Kompas, p. page 14.

[9] A. Wibowo and Hamrin, Menjadi Guru Berkarakter: Strategi Membangun Kompetensi \& Karakter Guru. Yogyakarta: Pustaka Pelajar, 2012.

[10] T. Lickona, Educating for Character. Bandung: Remaja Rosda Karya, 2012.

[11] F. Muin, Pendidikan Karakter: Konstruksi Teoritik dan Praktik. Yogyakarta: Ar-Ruzz Media, 2011.

[12] R. Megawangi, Pendidikan Karakter Solusi yang Tepat untuk Membangun Bangsa. Jakarta: BP Migas dan Star Energy, 2004.

[13] F. M. Hidayatullah, "Pendidikan Karakter," in Seminar Nasional Pembangunan Karakter Bangsa. 